\title{
Pharmacy in Brazil: Progress and Challenges on the Road to Expanding Clinical Practice
}

\author{
Angelita Cristine Melo, Dayani Galato, Hellen Karoline Maniero, Josélia Cintya Quintão Pena Frade, \\ Tarcisio José Palhano, Wellington Barros da Silva, and Walter da Silva Jorge João
}

\section{INTRODUCTION}

$\mathrm{B}$ razil is a vast country with a total surface area of 8.5 million $\mathrm{km}^{2}$, covering $47 \%$ of South America. ${ }^{1}$ It is the fifth most populous country in the world, with a population estimated at more than 207 million in $2015 .^{2}$ The country is divided into 5 regions encompassing 26 states, 1 Federal District (Brasília), and 5570 municipalities.

Brazil is a country of continental dimensions, and plenty of diversity exists with regard to both human development and the health needs of its population. The states with the largest areas have low population densities because of environmental issues, such as a high concentration of rivers and wetlands, which hinder settlement; furthermore, the provision of health care services is a challenge because of population dispersal. ${ }^{3}$ This variability also affects the pharmaceutical practices and profiles of pharmacies (Figure 1).

In this context, this article presents information about pharmaceutical practice in Brazil and how it is organized, according to the "building blocks" of the World Health Organization's Health Systems Framework.

Over the past few decades, the demographic and epidemiological profiles of Brazil have changed. Currently, the country's profile is similar to those of other developed countries. In 1991, the average life expectancy at birth was 66.9 years; by 2013, this value had increased to 78.5 years for women and 71.2 years for men. ${ }^{4}$ Similarly, infant mortality rates have decreased by $70.7 \%$ over 25 years. Birth rates have also decreased by $39.3 \%$, from 23.4 per thousand in $1991^{5}$ to 14.2 per thousand in $2013 .^{6}$

Today, the Brazilian population is experiencing a double burden of disease, related to both noncommunicable and communicable diseases. As the epidemiological transition begins, noncommunicable diseases are starting to replace communicable diseases; however, infectious conditions continue to be highly prevalent in the country. ${ }^{7,8}$ In Brazil and other countries, a high burden of noncommunicable diseases exists, accounting for $72 \%$ of all deaths. ${ }^{9}$ The major causes of death include cardiovascular disease (30.7\%), cancer (16.9\%), external causes (13.4\%), and respiratory disease (11.6\%). ${ }^{5}$ The death rates due to infectious diseases were $6.2 \%$ in 1990 and $4.5 \%$ in 2011. Improvements in access to basic sanitation services, the development of new technologies, and the expansion of access to health care services are some of the interventions responsible for this reduction. ${ }^{5}$

\section{HEALTH SYSTEM LEADERSHIP, GOVERNANCE, AND HEALTH CARE FINANCING}

In Brazil, structuring of the public health care system began in 1808. However, the national public health care system (NPHS), known as Sistema Único de Saúde, was created in 1990, through the Federal Constitution ${ }^{10}$ and Federal Law $8.080 / 1990,{ }^{*}$ following a social movement to change the way in which health care was delivered. ${ }^{11}$ The National Pharmaceutical Policies of 1998, along with Resolution 338/2004, also guaranteed access to medicine through this system. ${ }^{12}$

The NPHS is organized by region and levels of complexity of care. It is based on 3 health principles: universality, equality, and integrality. ${ }^{11}$ These principles imply the provision of high-quality health services for all patients, regardless of geographic location or health condition, to reduce health care inequalities. The public health budget is financed primarily through taxes and is shared by a tripartite alliance for public health care provision (i.e., the national, state, and municipal governments). The financing and transfer of federal funds for health care services, as well as the monitoring and control of these services, are regulated by federal law (Directive 204/2007).

\footnotetext{
*Additional details for legislative and regulatory documents are provided in Appendix 1, available at www.cjhp-online.ca/ index.php/cjhp/ issue/view/123/show Toc
} 


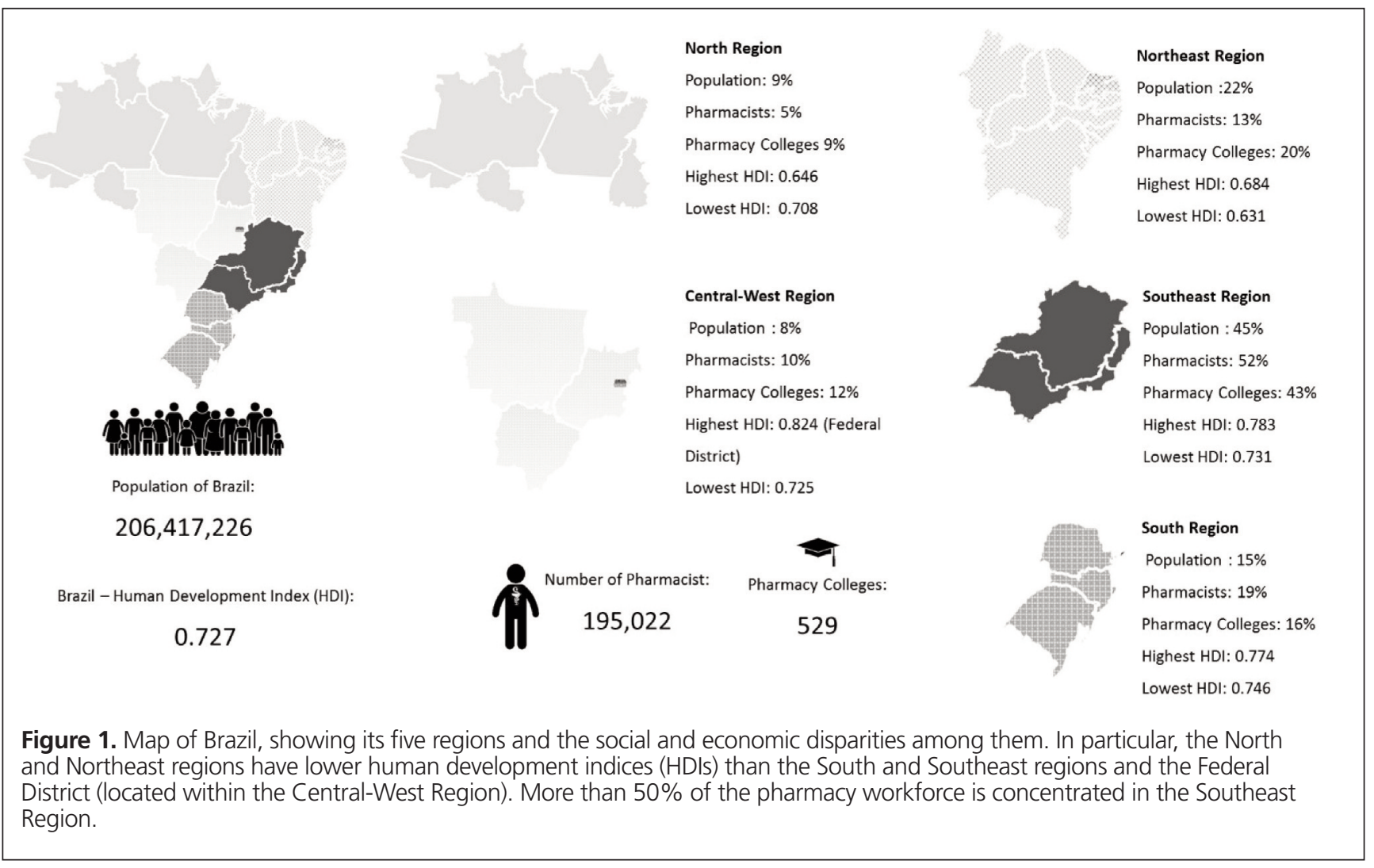

This process is divided into 6 funding blocks: primary care, secondary and tertiary care (outpatient and hospital), health surveillance, pharmaceutical assistance, NPHS management, and investments in the health care services network. ${ }^{13}$

The NPHS is the largest public health care system in the world and is also the largest public organ transplant system. It is associated with 3.7 billion outpatient procedures per year, 1 million hospital admissions per month, and about 500 million medical consultations in 2012 alone. ${ }^{14}$ The NPHS has 6690 hospitals, $70 \%$ of which are private and able to meet the demands of the system through agreements with the Brazilian government. ${ }^{15}$ The NPHS also has more than 38000 public primary care units ${ }^{16}$ and 79990 community pharmacies. ${ }^{17}$ In $2013,79 \%$ of total government expenditures on health was for public health, and $19 \%$ was for private health. ${ }^{18}$

In 2007 , this spending represented $3.5 \%$ of the gross domestic product (GDP), ${ }^{19}$ and this proportion remained similar in 2013 (3.6\%). In contrast, total expenditures by households and nonprofit institutions was 4.4\% of GDP in 2013 or $\$ 158.801$ billion in Canadian dollars. Total spending on health by government, nonprofit institutions, and households summed to about $8.0 \%$ of GDP in that year. ${ }^{18}$

Despite this financial provision, Brazilian families spent 9 times more than the public expenditure on medicines in 2013. ${ }^{18}$ A partial explanation of this finding is associated with increasing health care costs. The per capita expenditure on health has increased significantly in recent years, from Can $\$ 76.73$ in 2000 to Can $\$ 338.39$ in $2012 .{ }^{5}$

\section{HEALTH CARE WORKFORCE}

In Brazil, the organization of professions is regulated by profession-specific federal laws that delegate the right to selfregulate professional practice to professional associations. In the case of pharmacy, the Brazilian Federal Council of Pharmacy (Conselho Federal de Farmácia or CFF) regulates and establishes the standards of pharmaceutical practice. There are also scientific pharmaceutical societies, which are professional, scientific, humanitarian, and cultural nonprofit associations that seek to qualify professionals, perform research and teach, and perform accreditation for services and education. However, they do not have the authority to regulate the profession.

The Ministry of Labour and Employment (Ministério do Trabalho e Emprego) has established a classification system of occupations, known as the Brazilian Classification of Occupations (Classificação Brasileira de Ocupaçôes or $\mathrm{CBO}$ ), which determines the possibilities for work. Until January 2013, the pharmacy profession was limited to 2 occupations: pharmacist and biochemical pharmacist. After negotiations with the CFF, this classification was updated to address structural changes in the labour market. The current classification for the profession of pharmacy consists of 8 major occupational areas: pharmacist, 
clinical analyst pharmacist, food industry pharmacist, complementary and integrative practice pharmacist, public health pharmacist, pharmaceutical industry pharmacist, toxicology pharmacist, and hospital and clinical pharmacist. ${ }^{20}$ Subsequent to this review and update of the classification, however, several changes in pharmaceutical practice have occurred, arising from Resolutions 585/2013 and 586/2013 and Federal Law 13021/2014, as well as Resolution 581/2013, the latter establishing the title of professional specialist for pharmacists in Brazil, which includes the possibility of obtaining the title of specialist in clinical pharmacy. Furthermore, a conceptual framework for clinical services has also been published (Serviços farmacêuticos diretamente destinados ao paciente, à família $e$ à comunidade contextualização e arcabouço conceitual or "Pharmaceutical services directly aimed at the patient, family and community: contextualization and conceptual framework"), ${ }^{21}$ and its content modifies what is proposed in the Brazilian Classification of Occupations, ${ }^{22-24}$ particularly with regard to clinical pharmacy, which justifies a further revision of this classification in Brazil.

In terms of remuneration, pharmacists are remunerated according to the institution with which they are affiliated (either public or private) and according to the position they hold.

\section{Dimensions of Brazilian Pharmacy}

In the Brazilian health care system, nursing is the largest profession, with 1.8 million members, followed by medicine, with 378000 physicians. In 2015, pharmacy was the thirdlargest health care workforce, with 195022 pharmacists, most of whom were women (64\%). Pharmacists worked in 101478 different establishments, most of which were private pharmacies $(n=79990,78.8 \%)$. Of this total, only $9.0 \%$ were compounding pharmacies, and $1.2 \%$ were homeopathic pharmacies. The second most common job location for pharmacists was in public pharmacies $(n=10463$ establishments, $10.3 \%)$, followed by hospital pharmacies $(n=6539,6.4 \%)$ and medicinal product distributors $(n=4030,4.0 \%)$. The pharmaceutical industry represented a small employment sector, with 456 different institutions (0.4\%). Clinical analysis was an area that showed a decline in available jobs for new professionals; however, clinical analysis remains important, with 9729 laboratories in $2015 .{ }^{17}$

\section{Education and Training}

The pharmacy workforce increases by 18500 pharmacists each year. The pharmacy curriculum is 4 years in duration, with a minimum of $4000 \mathrm{~h}$ of training, and up to $20 \%$ of this workload can be obtained via distance learning (Resolution CNE/CES 2/2002 and Federal Law 9.394/1996). The entry point for students at graduation usually occurs by direct selection. Some institutions offer an interdisciplinary bachelor's degree in health for the first degree cycle. ${ }^{25}$ In Brazil, one requirement for completion of the curriculum is an internship with a minimum workload corresponding to $20 \%$ of the pharmacy course workload (i.e., at least 800 h). ${ }^{23}$

The current National Curriculum Guidelines for Pharmacy state that pharmacists must develop an understanding of drugs and medicines (i.e., their dispensing and manipulation, as well as the industry more generally), clinical and toxicological analyses, the food industry (production and analysis), and the provision of health care. ${ }^{25}$ However, this curriculum has proved too extensive for the workload allowed. Therefore, in 2015 and 2016, a new national proposal was created to remodel the training of pharmacists along 3 axes: health care provision, management, and technology/innovation. ${ }^{23,26}$ In addition, a guide was developed toward student-centred learning, with active learning methodologies and training based on the community, especially with regard to the primary public health care system. ${ }^{26}$ However, unlike the situation in other countries, there has been no change in the type of diploma (such as conversion to the PharmD degree, as is now available in the United States and Canada). Rather, all students graduate with a Bachelor of Pharmacy (BPharm).

The standards of competencies for clinical pharmacists are organized into 3 major areas: family and community care; patient care; and organization and management of services, and professional and personal development for health care provision (Figure 2). ${ }^{27}$ Details are presented in Appendix 2 (available at www.cjhp-online.ca/index.php/cjhp/issue/view/123/showToc). ${ }^{22,28,29}$

\section{Postgraduate Programs}

Two types of postgraduate programs exist in Brazil: one at higher education institutions, with an academic purpose (postgraduate programs sensu stricto), and the other aimed at professional qualification (postgraduate programs sensu lato). The latter type also includes residencies.

Postgraduate programs sensu stricto, which include master's-level and doctoral programs, are subject to authorization requirements and renewal of accreditation provided through legislation of the Ministry of Education. ${ }^{30}$

Postgraduate programs sensu lato, which include specialization courses (e.g., Master in Business Administration), are offered by higher education institutions and are subject to independent authorization requirements and renewal of accreditation. Importantly, the autonomy of higher education institutions prevails over the teaching proposal in the case of academic specialization (as per Technical Note 386/2013). The courses must have a minimum duration of $360 \mathrm{~h}$, and time must be reserved to prepare an individual monograph or final course assignment. Furthermore, at least $50 \%$ of the teachers must have a master's or doctoral degree recognized by the Ministry of 


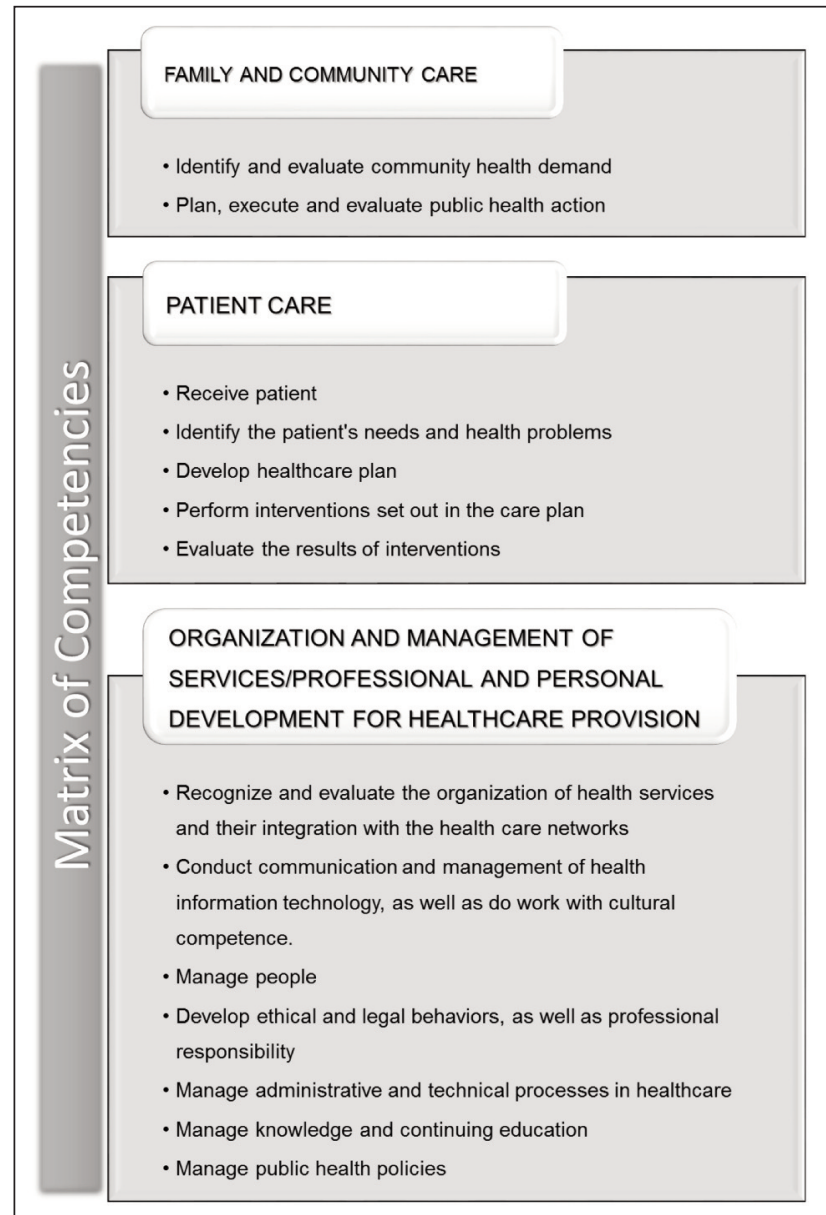

Figure 2. Core competencies of clinical pharmaicists in Brazil and required aspects of performance. Source: Brazilian Federal Council of Pharmacy. Translation from original Portuguese. Reproduced with permission.

Education (as per Technical Note 386/2013). Unfortunately, it is not known how many of these types of courses exist. Some courses, called cursos livres, are regulated and recognized by the CFF (Resolution 582/2013). This recognition occurs through verification of workload adequacy and a minimum referential process stating that the courses must include $300 \mathrm{~h}$, of which $100 \mathrm{~h}$ must be theoretical activities that can be performed as distance learning with face-to-face assessments. The practical content must involve $200 \mathrm{~h}$, of which at least $60 \%$ should be performed using real-world scenarios. Moreover, the practical classes should have no more than 12 students for every teacher. ${ }^{24}$

Residency programs, which can be multidisciplinary or limited to a specific health profession such as pharmacy, were created by Federal Law 11.129 in 2005. Usually, residencies are carried out in a hospital environment or in basic health units. Depending on the program, there may be rotations in different practice environments, such as ambulatory or intensive care. Each residency has a minimum duration of 2 years, with a minimum of $5760 \mathrm{~h}$, of which $80 \%$ must be dedicated to practical and theoretical-practical activities guided by the
NPHS. Entrance requires a thorough public selection process, and a scholarship (Can\$1164.33 monthly) is paid to each resident (Federal Law 11.129/2005). The Multidisciplinary Residency in Health program encourages practice in patient care, aligned to recent changes in professional regulations. In Brazil, 938 residency programs are in operation, of which 136 are multidisciplinary, including a residency in pharmacy, and 8 are in health profession areas that focus exclusively on pharmacy. Only 1 program focuses on clinical analysis. In 2014, multidisciplinary residency programs had 428 vacancies for pharmacists, but this number is relatively small, given that more than 18500 students completed undergraduate pharmacy courses in 2014. ${ }^{31}$

\section{National System for Higher Education Evaluation and Continuing Professional Development}

Undergraduate courses are subject to evaluations conducted through the National System for Higher Education Evaluation (Sistema Nacional de Avaliação do Ensino Superior or SINAES) (as per Federal Law 10.861/2004). This system consists of 3 major evaluations, covering institutions, courses, and student performance. ${ }^{32}$

Students are evaluated through the National Examination of Student Performance (Exame Nacional do Ensino Superior or ENADE). This exam is a requirement for obtaining a diploma. The exam was first administered in 2004, and the maximum frequency of evaluation is every 3 years for each area of knowledge. The results of all evaluations provide an overview of the quality of the courses and higher education institutions in Brazil. ${ }^{33}$

All health care professionals in Brazil are considered able to practise once they graduate; however, they must be registered with a regional council of the state where they are to practise. This council is part of a national system, for which the CFF is the governing body (Federal Law 3.820/1960). After initial registration, pharmacists are not required to register yearly or to repeat the certification process to maintain professional qualifications. Rather, they must be available for inspection by the CFF and the health authority (Resolution CNE/CES 2/2002). The idea is that over time, health care professionals gain experience in one or more areas, but they do not need to demonstrate ongoing maintenance of competency. Educators and the CFF are sensitive to the need to change this perception, but many legal impediments must first be addressed before implementation of performance reviews and levels, re-registration, change or expansion of a role, credentialing, or other tests are used to evaluate competency.

\section{Development of Clinical Pharmacy}

Clinical pharmacy in Brazil began in 1979 at the Clinical Hospital of the Federal University of Rio Grande do Norte. Because of the small number of professionals and the size of the 
country, the number of clinical services increased only slowly in hospitals, pharmacies, and public primary care units, despite efforts to speed up the process. ${ }^{34}$ In 2002, a proposal from the Brazilian Consensus on Pharmaceutical Care helped to address this problem and was incorporated into the National Pharmaceutical Assistance Policy. ${ }^{35}$

The CFF has defined clinical pharmacy as a pharmaceutical field geared toward the awareness and practice of the rational use of drugs, in which pharmacists provide the patient with care to optimize pharmacotherapy, promote health and well-being, and prevent illnesses (Resolution 585/2013).

Despite these advances, clinical practice remains fragmented and insufficient in Brazil. More recently, the CFF has made plans and deployed various strategies to foster clinical pharmacy in Brazil, including regulating the professional scope (Resolutions 585/2013 and 586/2013, Federal Law 13021/2014), forming health regulations (such as Resolution RDC 44/2009), and creating the Support Programme for Pharmaceutical Care in Healthcare (Programa de Suporte ao Cuidado Farmacêutico na Atenção à Saúde or ProFar). ProFar has put forward various proposals for developing clinical practice guidelines ${ }^{36}$ health care education programs to provide health care services, and documents for practice in Brazil, such as "Pharmaceutical services directly aimed at the patient, family and community: contextualization and conceptual framework" (Figure 3). ${ }^{21}$

The Ministry of Health, through the Department of Pharmaceutical Assistance and Strategic Inputs (Departamento de Assistência Farmacêutica e Insumos Estratégicos or DAF), has sought to develop various strategies to implement the guidelines of the National Drug Policy and National Pharmaceutical Assistance Policy (including Resolution 338/2004). ${ }^{12}$ The DAF aims to formulate and coordinate the management of these policies and to standardize, organize, promote, and coordinate the acquisition and distribution of strategic inputs for health and pharmaceutical services at different levels of health care. In 2012, the DAF presented a pilot project for the implementation of pharmaceutical clinical services in regional health care networks, with the goal of contributing to the qualification of professionals to better serve the population. ${ }^{37}$

\section{Pharmacy Technicians}

The pharmacy technician profession includes only professionals with a bachelor's degree in pharmacy; no regulations currently exist for technicians (Federal Law 3.820/1960). Technical training courses are offered without any regulation or inspection. In pharmacies, the activities of pharmacy technicians are the sole responsibility of the pharmacist. However, a movement exists for the CFF to implement and regulate registration of pharmacy technicians under the supervision of a pharmacist.

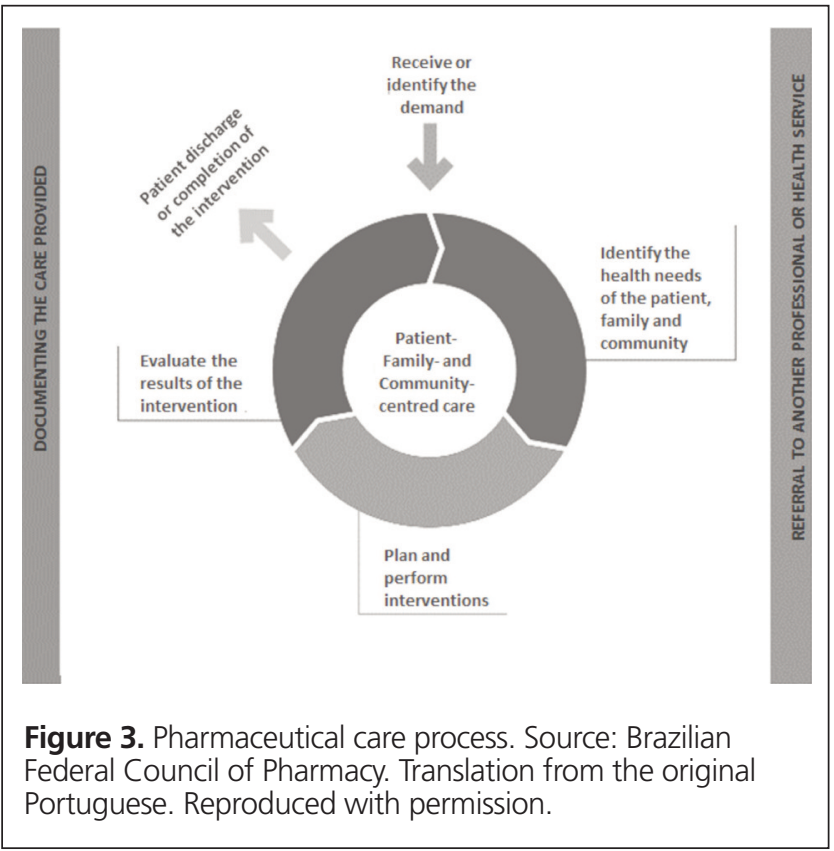

\section{Pharmacy Professional Societies}

Thirteen professional pharmacy societies exist in Brazil, corresponding to the various areas of pharmaceutical practice in the country (see Table 1).

\section{Prescriptive Authority}

Prescriptions are written by physicians, dentists (restricted to medications used in their specialty), and veterinarians (for animals only) (Decree 20.931/1932, Federal Law 5.081/1966, Directive 344/1998). Nevertheless, over time, other health care professionals have been permitted to prescribe, with consideration of their specific limits as nurses, nutritionists, physiotherapists, or pharmacists.

In the profession of nursing, the term "prescription" is used in a broader sense (Federal Law 7.498/1986, Decree $94.406 / 1987)$. In 2007 , nurses ability to prescribe was expanded to encompass medicinal products and complementary exams in public health programs (Directives 1.625/2007 and $2.488 / 2011)$. Similarly, dietetic prescription is a private act of nutritionists; in this case, the term "prescription" also has substantial meaning (Federal Law 8.234/1991, Resolution CFN 304/2003). For example, nutritional supplements to complement diet and nutrition can be prescribed as part of daily dietary intake (Resolution RDC 269/2005), and natural herbal medicines and fresh vegetables were approved as prescription drugs in 2007 (Resolution CFN 402/2007). In addition, physiotherapists can prescribe floral therapy and natural herbal medicines or fresh vegetables as drugs (Resolution COFFITO 380/2010).

In Brazil, the possibility of prescribing by pharmacists is implicit in various regulations both for over-the-counter drugs 
This single copy is for your personal, non-commercial use only.

For permission to reprint multiple copies or to order presentation-ready copies for distribution, contact CHHP at publications@cshp.ca

\section{Table 1. Professional Pharmacy Societies and Technology Network in Brazil}

\section{Society}

National Association of Pharmacists

Practicing in Logistics (Portuguese:

Anfarlog)

\section{Date of Founding}

This society aims to develop professionals

and companies in the private sector; support the implementation of standards and criteria; and develop, coordinate, and implement certification for the transportation and storage sectors.

Brazilian Pharmacists Association (Portuguese: Associação Brasileira de Farmacêuticos)

National Academy of Pharmacy (Portuguese: Academia Nacional de Farmácia)

\begin{tabular}{|c|c|c|c|}
\hline & & & \\
\hline $\begin{array}{l}\text { National Academy of Pharmacy } \\
\text { (Portuguese: Academia Nacional } \\
\text { de Farmácia) }\end{array}$ & 1937 & $\begin{array}{l}\text { This society studies, discusses, disseminates, } \\
\text { educates, and collaborates as an advisory } \\
\text { body on national and international activities } \\
\text { with regard to all that relates to the } \\
\text { pharmaceutical sciences. }\end{array}$ & $\begin{array}{l}\text { www.academiafarmacia. } \\
\text { org.br/institucional.php }\end{array}$ \\
\hline $\begin{array}{l}\text { Brazilian Society of Clinical Analysis } \\
\text { (Portuguese: SBAC) }\end{array}$ & 1967 & $\begin{array}{l}\text { This society aims to develop clinical } \\
\text { laboratories and the specialty of clinical } \\
\text { analysis. }\end{array}$ & www.sbac.org.br/sbac/ \\
\hline $\begin{array}{l}\text { Brazilian Society of Pharmacognosy } \\
\text { (Portuguese: SBFgnosia) }\end{array}$ & 1976 & $\begin{array}{l}\text { This scientific society was founded by } \\
\text { professors, researchers, and professionals } \\
\text { who believe in the importance of } \\
\text { pharmacognosy for society. }\end{array}$ & $\begin{array}{l}\text { www.sbfgnosia.org.br/ } \\
\text { index.html }\end{array}$ \\
\hline $\begin{array}{l}\text { National Pharmacist Association of } \\
\text { Compounding Pharmacy } \\
\text { (Portuguese: Anfarmag) }\end{array}$ & 1986 & $\begin{array}{l}\text { This society represents both pharmacies } \\
\text { and pharmacists. }\end{array}$ & $\begin{array}{l}\text { www.anfarmag.com.br/ } \\
\text { a-entidade }\end{array}$ \\
\hline $\begin{array}{l}\text { Brazilian Association of Homeopathic } \\
\text { Pharmacists (Portuguese: ABFH) }\end{array}$ & 1990 & $\begin{array}{l}\text { This association disseminates, develops, and } \\
\text { certifies knowledge based on homeopathy, } \\
\text { involving citizens and society in the pursuit } \\
\text { of health and quality of life. }\end{array}$ & http://abfh.org.br/sobre/ \\
\hline $\begin{array}{l}\text { Brazilian Society of Hospital Pharmacy } \\
\text { and Healthcare Services } \\
\text { (Portuguese: SBRAFH) }\end{array}$ & 1995 & $\begin{array}{l}\text { This professional association is designed to } \\
\text { contribute to the integration of hospital } \\
\text { pharmacists, encourage the development } \\
\text { of pharmacy in health care services, and } \\
\text { support scientific, cultural, and social activities }\end{array}$ & $\begin{array}{l}\text { www.sbrafh.org.br/site/ } \\
\text { public/docs/ } \\
\text { EstatutoSBRAFH_2014.pdf } \\
\text { s. }\end{array}$ \\
\hline $\begin{array}{l}\text { Brazilian Society of Oncology } \\
\text { Pharmacists (Portuguese: SOBRAFO) }\end{array}$ & 2001 & $\begin{array}{l}\text { This association is dedicated to pharmacy } \\
\text { professionals in oncology in Brazil. }\end{array}$ & $\begin{array}{l}\text { www.sobrafo.org.br/site/ } \\
\text { institucional }\end{array}$ \\
\hline $\begin{array}{l}\text { Brazilian Association of } \\
\text { Pharmaceutical Sciences } \\
\text { (Portuguese: ABCF) }\end{array}$ & 2003 & $\begin{array}{l}\text { This association seeks to support } \\
\text { pharmaceutical sciences within the country } \\
\text { and abroad, as well as supporting the } \\
\text { development of continuing education } \\
\text { programs. }\end{array}$ & $\begin{array}{l}\text { www.abcfarm.org.br/ } \\
\text { associacao.php }\end{array}$ \\
\hline $\begin{array}{l}\text { Brazilian Society of Pharmaceutical } \\
\text { Acupuncturists (Portuguese: Sobrafa) }\end{array}$ & 2005 & $\begin{array}{l}\text { This society brings together pharmaceutical } \\
\text { professionals who practise acupuncture } \\
\text { in Brazil. }\end{array}$ & $\begin{array}{l}\text { www.sobrafa.org.br/v1/ } \\
\text { index.php/component } \\
\text { /content/category/91-sobrafa }\end{array}$ \\
\hline $\begin{array}{l}\text { Brazilian Society of Pharmacists and } \\
\text { Community Pharmacies } \\
\text { (Portuguese: SBFFC) }\end{array}$ & 2009 & $\begin{array}{l}\text { This society aims to develop scientific events, } \\
\text { research activities, advisory services, and the } \\
\text { professional training of pharmacists who } \\
\text { practise in public and private pharmacies } \\
\text { with the disclosure of pharmaceutical care } \\
\text { and pharmaceutical services. }\end{array}$ & $\begin{array}{l}\text { www.sbffc.org.br/ } \\
\text { paginas.php?id=29 }\end{array}$ \\
\hline $\begin{array}{l}\text { National Network for Technology } \\
\text { Assessments in Health (Portuguese: } \\
\text { Rede Brasileira de Avaliação de } \\
\text { Tecnologias em Saúde) }\end{array}$ & 2016 & & http://rebrats.saude.gov.br/ \\
\hline Brazilian Society of Clinical Pharmacy & 2017 & $\begin{array}{l}\text { This new society brings together pharmacists, } \\
\text { students, and researchers interested in the } \\
\text { fields of clinical pharmacy and } \\
\text { pharmaceutical care. }\end{array}$ & \\
\hline
\end{tabular}

Brazilian Society of Pharmacognosy (Portuguese: SBFgnosia)

\begin{tabular}{|c|c|c|c|}
\hline & & & \\
\hline $\begin{array}{l}\text { National Academy of Pharmacy } \\
\text { (Portuguese: Academia Nacional } \\
\text { de Farmácia) }\end{array}$ & 1937 & $\begin{array}{l}\text { This society studies, discusses, disseminates, } \\
\text { educates, and collaborates as an advisory } \\
\text { body on national and international activities } \\
\text { with regard to all that relates to the } \\
\text { pharmaceutical sciences. }\end{array}$ & $\begin{array}{l}\text { www.academiafarmacia. } \\
\text { org.br/institucional.php }\end{array}$ \\
\hline $\begin{array}{l}\text { Brazilian Society of Clinical Analysis } \\
\text { (Portuguese: SBAC) }\end{array}$ & 1967 & $\begin{array}{l}\text { This society aims to develop clinical } \\
\text { laboratories and the specialty of clinical } \\
\text { analysis. }\end{array}$ & www.sbac.org.br/sbac/ \\
\hline $\begin{array}{l}\text { Brazilian Society of Pharmacognosy } \\
\text { (Portuguese: SBFgnosia) }\end{array}$ & 1976 & $\begin{array}{l}\text { This scientific society was founded by } \\
\text { professors, researchers, and professionals } \\
\text { who believe in the importance of } \\
\text { pharmacognosy for society. }\end{array}$ & $\begin{array}{l}\text { www.sbfgnosia.org.br/ } \\
\text { index.html }\end{array}$ \\
\hline $\begin{array}{l}\text { National Pharmacist Association of } \\
\text { Compounding Pharmacy } \\
\text { (Portuguese: Anfarmag) }\end{array}$ & 1986 & $\begin{array}{l}\text { This society represents both pharmacies } \\
\text { and pharmacists. }\end{array}$ & $\begin{array}{l}\text { www.anfarmag.com.br/ } \\
\text { a-entidade }\end{array}$ \\
\hline $\begin{array}{l}\text { Brazilian Association of Homeopathic } \\
\text { Pharmacists (Portuguese: ABFH) }\end{array}$ & 1990 & $\begin{array}{l}\text { This association disseminates, develops, and } \\
\text { certifies knowledge based on homeopathy, } \\
\text { involving citizens and society in the pursuit } \\
\text { of health and quality of life. }\end{array}$ & http://abfh.org.br/sobre/ \\
\hline $\begin{array}{l}\text { Brazilian Society of Hospital Pharmacy } \\
\text { and Healthcare Services } \\
\text { (Portuguese: SBRAFH) }\end{array}$ & 1995 & $\begin{array}{l}\text { This professional association is designed to } \\
\text { contribute to the integration of hospital } \\
\text { pharmacists, encourage the development } \\
\text { of pharmacy in health care services, and } \\
\text { support scientific, cultural, and social activities }\end{array}$ & $\begin{array}{l}\text { www.sbrafh.org.br/site/ } \\
\text { public/docs/ } \\
\text { EstatutoSBRAFH_2014.pdf } \\
\text { s. }\end{array}$ \\
\hline $\begin{array}{l}\text { Brazilian Society of Oncology } \\
\text { Pharmacists (Portuguese: SOBRAFO) }\end{array}$ & 2001 & $\begin{array}{l}\text { This association is dedicated to pharmacy } \\
\text { professionals in oncology in Brazil. }\end{array}$ & $\begin{array}{l}\text { www.sobrafo.org.br/site/ } \\
\text { institucional }\end{array}$ \\
\hline $\begin{array}{l}\text { Brazilian Association of } \\
\text { Pharmaceutical Sciences } \\
\text { (Portuguese: ABCF) }\end{array}$ & 2003 & $\begin{array}{l}\text { This association seeks to support } \\
\text { pharmaceutical sciences within the country } \\
\text { and abroad, as well as supporting the } \\
\text { development of continuing education } \\
\text { programs. }\end{array}$ & $\begin{array}{l}\text { www.abcfarm.org.br/ } \\
\text { associacao.php }\end{array}$ \\
\hline $\begin{array}{l}\text { Brazilian Society of Pharmaceutical } \\
\text { Acupuncturists (Portuguese: Sobrafa) }\end{array}$ & 2005 & $\begin{array}{l}\text { This society brings together pharmaceutical } \\
\text { professionals who practise acupuncture } \\
\text { in Brazil. }\end{array}$ & $\begin{array}{l}\text { www.sobrafa.org.br/v1/ } \\
\text { index.php/component } \\
\text { /content/category/91-sobrafa }\end{array}$ \\
\hline $\begin{array}{l}\text { Brazilian Society of Pharmacists and } \\
\text { Community Pharmacies } \\
\text { (Portuguese: SBFFC) }\end{array}$ & 2009 & $\begin{array}{l}\text { This society aims to develop scientific events, } \\
\text { research activities, advisory services, and the } \\
\text { professional training of pharmacists who } \\
\text { practise in public and private pharmacies } \\
\text { with the disclosure of pharmaceutical care } \\
\text { and pharmaceutical services. }\end{array}$ & $\begin{array}{l}\text { www.sbffc.org.br/ } \\
\text { paginas.php?id=29 }\end{array}$ \\
\hline $\begin{array}{l}\text { National Network for Technology } \\
\text { Assessments in Health (Portuguese: } \\
\text { Rede Brasileira de Avaliação de } \\
\text { Tecnologias em Saúde) }\end{array}$ & 2016 & & http://rebrats.saude.gov.br/ \\
\hline Brazilian Society of Clinical Pharmacy & 2017 & $\begin{array}{l}\text { This new society brings together pharmacists, } \\
\text { students, and researchers interested in the } \\
\text { fields of clinical pharmacy and } \\
\text { pharmaceutical care. }\end{array}$ & \\
\hline
\end{tabular}

Portuguese: SBRAFH)

\begin{tabular}{|c|c|c|c|}
\hline & & & \\
\hline $\begin{array}{l}\text { National Academy of Pharmacy } \\
\text { (Portuguese: Academia Nacional } \\
\text { de Farmácia) }\end{array}$ & 1937 & $\begin{array}{l}\text { This society studies, discusses, disseminates, } \\
\text { educates, and collaborates as an advisory } \\
\text { body on national and international activities } \\
\text { with regard to all that relates to the } \\
\text { pharmaceutical sciences. }\end{array}$ & $\begin{array}{l}\text { www.academiafarmacia. } \\
\text { org.br/institucional.php }\end{array}$ \\
\hline $\begin{array}{l}\text { Brazilian Society of Clinical Analysis } \\
\text { (Portuguese: SBAC) }\end{array}$ & 1967 & $\begin{array}{l}\text { This society aims to develop clinical } \\
\text { laboratories and the specialty of clinical } \\
\text { analysis. }\end{array}$ & www.sbac.org.br/sbac/ \\
\hline $\begin{array}{l}\text { Brazilian Society of Pharmacognosy } \\
\text { (Portuguese: SBFgnosia) }\end{array}$ & 1976 & $\begin{array}{l}\text { This scientific society was founded by } \\
\text { professors, researchers, and professionals } \\
\text { who believe in the importance of } \\
\text { pharmacognosy for society. }\end{array}$ & $\begin{array}{l}\text { www.sbfgnosia.org.br/ } \\
\text { index.html }\end{array}$ \\
\hline $\begin{array}{l}\text { National Pharmacist Association of } \\
\text { Compounding Pharmacy } \\
\text { (Portuguese: Anfarmag) }\end{array}$ & 1986 & $\begin{array}{l}\text { This society represents both pharmacies } \\
\text { and pharmacists. }\end{array}$ & $\begin{array}{l}\text { www.anfarmag.com.br/ } \\
\text { a-entidade }\end{array}$ \\
\hline $\begin{array}{l}\text { Brazilian Association of Homeopathic } \\
\text { Pharmacists (Portuguese: ABFH) }\end{array}$ & 1990 & $\begin{array}{l}\text { This association disseminates, develops, and } \\
\text { certifies knowledge based on homeopathy, } \\
\text { involving citizens and society in the pursuit } \\
\text { of health and quality of life. }\end{array}$ & http://abfh.org.br/sobre/ \\
\hline $\begin{array}{l}\text { Brazilian Society of Hospital Pharmacy } \\
\text { and Healthcare Services } \\
\text { (Portuguese: SBRAFH) }\end{array}$ & 1995 & $\begin{array}{l}\text { This professional association is designed to } \\
\text { contribute to the integration of hospital } \\
\text { pharmacists, encourage the development } \\
\text { of pharmacy in health care services, and } \\
\text { support scientific, cultural, and social activities }\end{array}$ & $\begin{array}{l}\text { www.sbrafh.org.br/site/ } \\
\text { public/docs/ } \\
\text { EstatutoSBRAFH_2014.pdf } \\
\text { s. }\end{array}$ \\
\hline $\begin{array}{l}\text { Brazilian Society of Oncology } \\
\text { Pharmacists (Portuguese: SOBRAFO) }\end{array}$ & 2001 & $\begin{array}{l}\text { This association is dedicated to pharmacy } \\
\text { professionals in oncology in Brazil. }\end{array}$ & $\begin{array}{l}\text { www.sobrafo.org.br/site/ } \\
\text { institucional }\end{array}$ \\
\hline $\begin{array}{l}\text { Brazilian Association of } \\
\text { Pharmaceutical Sciences } \\
\text { (Portuguese: ABCF) }\end{array}$ & 2003 & $\begin{array}{l}\text { This association seeks to support } \\
\text { pharmaceutical sciences within the country } \\
\text { and abroad, as well as supporting the } \\
\text { development of continuing education } \\
\text { programs. }\end{array}$ & $\begin{array}{l}\text { www.abcfarm.org.br/ } \\
\text { associacao.php }\end{array}$ \\
\hline $\begin{array}{l}\text { Brazilian Society of Pharmaceutical } \\
\text { Acupuncturists (Portuguese: Sobrafa) }\end{array}$ & 2005 & $\begin{array}{l}\text { This society brings together pharmaceutical } \\
\text { professionals who practise acupuncture } \\
\text { in Brazil. }\end{array}$ & $\begin{array}{l}\text { www.sobrafa.org.br/v1/ } \\
\text { index.php/component } \\
\text { /content/category/91-sobrafa }\end{array}$ \\
\hline $\begin{array}{l}\text { Brazilian Society of Pharmacists and } \\
\text { Community Pharmacies } \\
\text { (Portuguese: SBFFC) }\end{array}$ & 2009 & $\begin{array}{l}\text { This society aims to develop scientific events, } \\
\text { research activities, advisory services, and the } \\
\text { professional training of pharmacists who } \\
\text { practise in public and private pharmacies } \\
\text { with the disclosure of pharmaceutical care } \\
\text { and pharmaceutical services. }\end{array}$ & $\begin{array}{l}\text { www.sbffc.org.br/ } \\
\text { paginas.php?id=29 }\end{array}$ \\
\hline $\begin{array}{l}\text { National Network for Technology } \\
\text { Assessments in Health (Portuguese: } \\
\text { Rede Brasileira de Avaliação de } \\
\text { Tecnologias em Saúde) }\end{array}$ & 2016 & & http://rebrats.saude.gov.br/ \\
\hline Brazilian Society of Clinical Pharmacy & 2017 & $\begin{array}{l}\text { This new society brings together pharmacists, } \\
\text { students, and researchers interested in the } \\
\text { fields of clinical pharmacy and } \\
\text { pharmaceutical care. }\end{array}$ & \\
\hline
\end{tabular}

Brazilian Association of

Pharmaceutical Sciences

(Portuguese: ABCF)

\section{Brazilian Society of Pharmaceutical} Acupuncturists (Portuguese: Sobrafa)

Brazilian Society of Pharmacists and Community Pharmacies

(Portuguese: SBFFC)

(where pharmacists act as independent prescribers) and for drugs continuously used for refills or therapy previously prescribed by a physician (where pharmacists act as dependent prescribers) (Federal Law 11.903/2009; Resolutions CFF 357/2001,
467/2007, 87/2008, 477/2008, RDC 44/2009, and 546/2011). The Brazilian Health Surveillance Agency (Anvisa) defines the lists of over-the-counter drugs (Federal Law 11.903/2009). Pharmacist prescribing is mentioned under the terms "responsible 
self-medication" (Resolution CFF 357/2001) and "nonmedical prescription" (Resolution RDC 44/2009). Resolution CFF 586/2013 details several aspects of pharmacy prescribing in Brazil.

In 2013, the CFF formally regulated pharmacist prescribing through publication of Resolutions 585/2013 and 586/2013. Similar to the situation in the fields of nursing and nutrition, the CFF adopted an expanded concept of pharmacist prescribing as an act, rather than a type of service. More specifically, pharmacist prescribing is the act of selecting (and then documenting) all necessary interventions in the health care plan-in keeping with the promotion, protection, and recovery of health or for disease prevention - within one's professional limits (Figure 3). The aforementioned interventions may include selection of certain products as pharmacological approaches or other interventions, such as nonpharmacological therapies, as well as referral to other professional services and requesting of patient exams. Documentation of the process involves documenting the patient's prescription and recording the care provided in the medical record. ${ }^{21}$

\section{HEALTH SERVICE DELIVERY}

\section{Primary Care Level}

At the primary care level, a strategic care plan exists to coordinate and interconnect projects and professional functions. The health service teams must act in an interdisciplinary way and be jointly responsible for patient care. This strategic plan enables health care services to be provided on a shared basis, with the aim of integrated health care to solve health problems with a high degree of decentralization and a strong presence in the national territories. ${ }^{38,39}$ The delivery of health care services occurs through 2 types of units: Basic Health Units (Unidade Básica de Saúde or UBS in Portuguese) and Family Health Programmes (Programa Saúde da Família or PSF in Portuguese). The PSF was implemented in 1994 as a team composed of a family doctor, a nurse, a nursing assistant, and 6 community health workers. This strategy is characterized as a gateway to a hierarchical and regionalized health system, and it can be used to manage the care of up to 4000 patients in defined territories (Directive 2.488/2011). The PSF has the assistance of specialists such as pharmacists at Family Health Support Centres (Núcleo de Apoio à Saúde da Família or NASF in Portuguese). The teams work toward health promotion, disease prevention, and recovery from frequent diseases and disorders to maintain the health of the community. ${ }^{38-40}$

There are also some public community pharmacies, which, in addition to dispensing essential medicines, offer access to the clinical services provided by pharmacists, such as health screening, health education, minor illness management, medication reconciliation, medication review, and medication therapy management. As noted earlier, private pharmacies are the most common workplaces for pharmacists. In these pharmacies, dispensing services and the management of minor illness services prevail ${ }^{21}$, however, pharmacists increasingly provide other clinical services. Recently, the Brazilian Association of Pharmacies and Drugstores (Associação Brasileira de Redes de Farmácias e Drogarias or Abrafarma in Portuguese) has expanded pharmaceutical services throughout the country. As a result, more than 700 new pharmaceutical offices were expected to open by the end of $2016 .{ }^{41}$ In addition, independent and private pharmaceutical offices exist that are not linked with private pharmacies.

\section{Secondary and Tertiary Care Levels}

The secondary care level is composed of specialized medical services, notably in endocrinology, cardiology, oncology, and infectious diseases, that cannot be provided through primary health care because of the complexity of the patient's condition. This care is generally provided through outpatient units, located in hospitals or elsewhere. The tertiary care level is responsible for the highest-complexity assistance with the greatest technology density (and is typically provided in hospitals). To access these levels of services in the NPHS, the patients is referred by primary care units. ${ }^{42}$ Patients with private health care coverage can access these levels directly.

\section{Patient Electronic Records}

Unfortunately, no electronic system for patient records has been implemented at the national level to facilitate communication among health care professionals. The Department of Informatics of the Brazilian public health care system (Departamento de Informática do Sistema Único de Saúde do Brasil or DATASUS) is developing a national patient electronic record system as part of a strategy to restructure health care information. ${ }^{43}$ Until this system becomes available, however, integration of different levels of the public health care system can occur only through manual referrals and counter-referrals (Directives 1.559/2008 and 4279/2010). Lack of an electronic prescription system in the Brazilian NPHS may be responsible for misdiagnosis, procedure solicitation, and incorrect use of medications, among other problems. Resolutions 555/2011 and 585/2013 established that it is a duty of the pharmacist to record in each patient's records the care provided.

\section{ACCESS TO MEDICINES, VACCINES, AND TECHNOLOGY}

Access to medicines in Brazil occurs through public and private pharmacies, with public pharmacies being responsible for most medicines. NPHS financing for pharmaceutical assistance is divided into 3 components: basic medicines, which 
meet the demands of essential medicines for primary care; strategic medicines, which are used to treat neglected diseases such as leprosy, tuberculosis, malaria, AIDS, and coagulopathy; and specialized medicines, which are high-cost medicines dispensed only under clinical protocols and therapeutic guidelines. The first 2 components are primarily dispensed at the municipal government level (i.e., decentralized model). Specialized medicines are dispensed only by the state government. ${ }^{44}$

Partnerships also exist with private pharmacies for dispensing drugs through a program known as the Popular Pharmacy of Brazil (Farmácia Popular do Brasil). Under this program, medicines for hypertension, diabetes, and asthma are distributed free of charge, and the Brazilian government covers $90 \%$ of the price of other medicines (Federal Law 10.858/2004).

Although the Popular Pharmacy of Brazil is an alternative, the country still has problems with access to medicines. In 2013, only $33.2 \%$ of patients received at least one of their prescribed medicines from the public health service. ${ }^{45}$ One study showed that, on average, $40 \%$ of the drugs prescribed in primary care were not available in public pharmacies when needed. ${ }^{46}$

According to the Federal Constitution, access to medical technology, diagnosis, and treatment is a civil right. ${ }^{10}$ Nevertheless, about $23 \%$ of Brazilians ${ }^{47}$ resort to the private system, which is divided into 2 subsectors: the classical liberal sector (composed of autonomous private services) and the supplementary health sector (composed of services financed by health plans and insurance and regulated by the National Agency of Supplementary Health [Agência Nacional de Saúde Suplementar]). Furthermore, the unreasonable incorporation of technologies generates a judicialization of health (the acquisition of technologies or services through legal action, such as lawsuits). In this sense, the Ministry of Health established the National Network for Technology Assessments in Health to streamline this process. ${ }^{48,49}$

Brazil has a National Immunization Program that defines vaccination schedules and considers epidemiological situations, risks, vulnerabilities, and social specificities with guidelines for vaccine administration. More than 300 million doses of vaccines, serums, and immunoglobulins are delivered annually to children, adolescents, adults, pregnant women, older adults, and the indigenous populations. ${ }^{50}$ Generally, the population has access to vaccinations free of charge in public health units. Vaccines can also be administered in private medical clinics; in the case of community pharmacies, regulation of this procedure was scheduled to occur in the second half of 2017.

The immunization program was developed within the public health care system and through a decentralized, articulated, hierarchical network. ${ }^{51}$ High vaccination coverage has resulted in the drastic reduction or elimination of vaccine-preventable diseases. ${ }^{52}$ Furthermore, Brazil has high vaccination coverage, reaching $85.36 \%$ of the target population in 2015.5

\section{FUTURE DIRECTIONS}

Recent advances in the field of clinical pharmacy in Brazil are undeniable, in terms of both professional and health care legislation and the expansion of services and pharmaceutical procedures directly aimed at patients, families, and the community. Although clinical pharmacy in Brazil is not yet consolidated to the same extent as in other countries, great strides have been made in recent years, particularly with regard to legislation and training, which are essential for future advances. Moreover, certain barriers must still be overcome, such as confrontations with the Council of Medicine, which has filed regional and state-level legal suits (thus far unsuccessful) aimed at suspending Resolutions 585/2013 and 586/2013 and the remuneration of pharmacists for the provision of services and procedures. Currently, nonpharmacists own most pharmacies, and pharmacists are hired on an hourly basis, usually without additional payment for clinical services. To improve remuneration, the specification of payments for pharmaceutical services and procedures in the public health system and private health plans, as well as expansion and sustainability of this practice in Brazil, is required.

Another challenge consists in improving the training of pharmacists. In undergraduate education, the basis for change is already being evaluated by the Ministry of Education, with a proposal to revise the current National Curriculum Guidelines for Pharmacy. However, no national system of accreditation and certification exists for the professional proficiency of pharmacists after graduation. Political and technical work will be needed to develop and implement such a system. The absence of clinical practice standards may be overcome by the creation of the Brazilian Society of Clinical Pharmacy, which was justified by the lack of standards. ProFar is one initiative that has contributed to the qualification of pharmacists.

Finally, for more rapid and sustainable advances in pharmacists' performance in Brazil, better communication is needed among the various sectors of society responsible for pharmacist training, health care regulation, professional practice regulation, and financing of clinical services provided to society, both publicly and privately. Despite all of these obstacles, pharmacy professionals have shown great assistance in both recognizing and responding to the health care needs of the population, which has improved the perception of pharmacists' value to society.

\section{References}

1. Countries: Brazil. Geneva (Switzerland): World Health Organization; 2016 [cited 2016 Jun 24]. Available from: who.int/countries/bra/en/

2. World health statistics 2016: monitoring health for the SDGs. Geneva (Switzerland): World Health Organization; 2016 [cited 2016 Jun 24]. Available from: www.who.int/gho/publications/world_health_statistics/2016/en/

3. Densidade demográfica 2010. Brasília (Brazil): Instituto Brasileiro de Geografia e Estatistica; 2010 [cited 2016 Aug 20]. Available from: ftp:// geoftp.ibge.gov.br/cartas_e_mapas/mapas_do_brasil/sociedade_e_economia/ mapas_murais/densidade_populacional_2010.pdf 
This single copy is for your personal, non-commercial use only.

For permission to reprint multiple copies or to order presentation-ready copies for distribution, contact CHP at publications@cshp.ca

4. Pesquisa Nacional de Saúde - PNS 2013: percep̧̧āo do estado de saúde, estilos de vida e doenças crônicas: Brasil, grandes regiōes e unidades da federação. Rio de Janeiro (Brazil): Instituto Brasileiro de Geografia e Estatística; 2013.

5. Indicadores e dados básicos. Brasília (Brazil): Ministério da Saúde, Datasus; 2012 [cited 2016 Jun 24]. Available from: http://tabnet.datasus.gov.br/ cgi/idb2012/matriz.htm

6. Brasil em Síntese. Brasília (Brazil): Instituto Brasileiro de Geografia e Estatística; 2015 [cited 2016 Jun 24]. Available from: http://brasilemsintese. ibge.gov.br/home-brasil-em-sintese

7. Borges MC, Santos LP, Zago AM, da Silva BG, da Silva SG, de Mola CL. Socioeconomic development of cities and risk factors for non-communicable diseases: a comparative study across Brazilian state capitals. J Public Health (Oxf). 2016;38(4):653-9.

8. Mpofu JJ, de Moura L, Farr SL, Malta DC, Iser BM, Ivata Bernal RT, et al. Associations between noncommunicable disease risk factors, race, education, and health insurance status among women of reproductive age in Brazil 2011. Prev Med Rep. 2016;3:333-7.

9. Schmidt MI, Duncan BB, Silva GA, Menezes AM, Monteiro CA, Barreto $\mathrm{SM}$, et al. Chronic noncommunicable diseases in Brazil: burden and current challenges. Lancet. 2011;377(9781):1949-61.

10. Constituição da República Federativa do Brasil de 1988. Brasília (Brazil): Presidência da República, Casa Civil, Subchefia para assuntos Jurídicos; 1988 [cited 2016 Jul 18]. Available from: www.planalto.gov.br/ccivil_03/ Constituicao/Constituicao.htm

11. Paim J, Travassos C, Almeida C, Bahia L, Macinko J. The Brazilian health system: history, advances, and challenges. Lancet. 2011;377(9779):1778-97.

12. Politica nacional de medicamentos. Brasília (Brazil): Ministério da Saúde, Secretaria de Políticas de Saúde, Departamento de Formulação de Políticas de Saúde; 2001 [cited 2016 Sep 22]. Available from: http://bvsms. saude.gov.br/bvs/publicacoes/politica_medicamentos.pdf

13. Fundo a fundo. Brasília (Brazil): Governo Federal, Fundo Nacional de Saúde, Ministério da Saúde; 2017 [cited 2017 Jan 24]. Available from: http:// portalfns.saude.gov.br/fundo-a-fundo

14. Audiência com Comissão de Defesa do Consumidor, Comissão de Seguridade Social e Família, Comissão de Fiscalizaçāo Financeira e Controle [slide presentation]. Brasília (Brazil): Câmara Legislativa; 2012 [cited 2016 Sep 22]. Available from: http://www2.camara.leg.br/atividade-legislativa/ comissoes/comissoes-permanentes/cssf/audiencias-publicas/audienciaspublicas-anteriores/audiencia-2013/audiencia-03.04/apresentacao-1

15. Dados do setor. Brasília (Brazil): Confederação Nacional de Saúde; 2016 [cited 2016 Jun 24]. Available from: www.cns.org.br/links/DADOS_ DO_SETOR.htm

16. SUS: a saúde do Brasil. Brasília (Brazil): Ministério da Saúde; 2011.

17. Relatório de atividades fiscais. Brasília (Brazil): Conselho Federal de Farmácia, Comissão de Fiscalização; 2014.

18. Conta-satélite de Saúde Brasil 2010-2013. Contas nacionais no 48. Brasília (Brazil): Instituto Brasileiro de Geografia e Estatística (IBGE); 2015.

19. Conta-satélite de Saúde Brasil 2005-2007. Contas nacionais $\mathrm{n}^{\circ} 29$. Brasília (Brazil): Instituto Brasileiro de Geografia e Estatística (IBGE); 2009.

20. Classificação Brasileira de ocupaçôes. Brasília (Brazil): Ministério do Trabalho e Emprego; [cited 2016 Jun 24]. Available from: www.mtecbo.gov.br/cbosite/ pages/pesquisas/BuscaPorTituloA-Z.jsf

21. [Pharmaceutical services directly aimed at the patient, family and community: contextualization and conceptual framework]. Brasília (Brazil): Conselho Federal de Farmácia; 2016 [cited 2016 Jul 22]. Available from: www.cff.org.br/pagina.php?id=778\&menu=778\&titulo=Publica\%C3\%A7 $\% \mathrm{C} 3 \% \mathrm{~B} 5$ es. Portuguese.

22. Matriz de competências para a formação do farmacêutico na área de farmácia clínica. Brasília (Brazil): Conselho Federal de Farmácia; 2016 [cited 2016 Sep 24]. Available from: www.cff.org.br/userfiles/Matriz\%20final\%2018_ 11_2016\%20(site)(3).pdf

23. Encontro nacional de educadores em farmácia clínica. Gramado (Brazil): Conselho Federal de Farmácia; 2015.

24. Referenciais mínimos: para o credenciamento de cursos livres em atuação clínica do farmacêutico (farmácia clínica/cuidado farmacêutico). Brasília (Brazil): Conselho Federal de Farmácia; 2016 [cited 2016 Nov 18]. Available from: www.cff.org.br/userfiles/REFERENCIAIS\%20M\%C3\%8DNIMOS.pdf
25. Grupo de Trabalho Instituido pela Portaria SESu/MEC. Referenciais orientadores para os bacharelados Interdisciplinares e similares. Brasília (Brazil): Ministério da Educação, Secretaria de Educação Superior; 2010 [cited 2016 Sep 20]. Available from: http://reuni.mec.gov.br/images/ stories/pdf/novo\%20-\%20bacharelados\%20interdisciplinares $\% 20-\% 20$ referenciais\%20orientadores\%20\%20novembro_2010\%20brasilia.pdf

26. II fórum nacional para discussão das diretrizes curriculares nacionais do curso de graduação em farmácia. Brasília (Brazil): Conselho Federal de Farmácia; 2016.

27. Proposta para a elaboração das diretrizes curriculares nacionais para o curso de graduação em Farmácia - COMENSINO/CAEF/ABEF. Brasília (Brazil): Conselho Federal de Farmácia; Associação Brasileira de Educação Farmacêutica; 2016 [cited 2016 Sep 20]. Available from: www.cff.org.br/ userfiles/file/PROPOSTAS\%20DE\%20DCN\%20FARM\%C3\%81CIA 20-10-05-2016.pdf

28. Consulta Pública n ${ }^{\circ}$ 01/2016: Matriz de competências para a atuação clínica do farmacêutico. Brasília (Brazil): Conselho Federal de Farmácia; 2016 [cited 2016 Sep 20]. Available from: www.cff.org.br/pagina.php?id=789\&titulo= Consulta+P\%C3\%BAblica+n\%C2\%BA+01\%2F2016

29. Encontro nacional de educadores em farmácia clínica (relatório) in prelo. Brasília (Brazil): Conselho Federal de Farmácia; 2015.

30. Pós stricto sensu: pós graduação stricto sensu: mestrado e doutorado. Brasília (Brazil): Ministerio da Educação; [cited 2016 Jul 18]. Available from: http://portal.mec.gov.br/pos-graduacao/pos-graduacao

31. Residência. Brasília (Brazil): Conselho Federal de Farmácia; 2016 [cited 2016 Jul 18]. Available from: http://comunicacaocff.wixsite.com/residencia/ourtroop

32. SINAES [National System for Higher Education Evaluation]. Brasília (Brazil): Instituto Nacional de Estudos; Pesquisas Educacionais Anísio Teixeira; 2016 [cited 2016 Jul 22]. Available from: http://portal.inep.gov.br/ superior-sinaes. Portuguese.

33. ENADE [National Examination of Student Performance]. Brasília (Brazil): Instituto Nacional de Estudos; Pesquisas Educacionais Anísio Teixeira; 2016 [cited 2016 Jul 22]. Available from: http://portal.inep.gov.br/web/guest/ enade. Portuguese.

34. Melo AC, Socolik I, Frade JCQP, Lopes MI, Palhano TJ. Curso online: prescrição farmacêutica no manejo de problemas de saúde autolimitados: módulo 1: unidade 1: histórico de construção das resoluçôes/CFF no 585/2013 e n 586/2013: linha do tempo e coletânea de documentos. Brasília (Brazil): Conselho Federal de Farmácia; 2016

35. Ivama AM, Noblat L, Castro MS, Oliveira NVBV, Jaramillo NM, Rech N. [Brazilian Consensus on Pharmaceutical Care: proposal.] Brasilia (Brazil): Organização Pan Americana da Saúde; 2002. Portuguese.

36. [Support Programme for Pharmaceutical Care in Healthcare.] Brasília (Brazil): Conselho Federal de Farmácia; 2016 [cited 2016 Jul 22]. Available from: www.cff.org.br/userfiles/file/_PROFAR_kit_Livro_corrigido.pdf. Portuguese.

37. [Planning and deployment of pharmaceutical care services in primary healthcare: the experience of Curitiba.] Brasília (Brazil): Ministério da Saúde; 2014 [cited 2016 Jul 22]. Available from: http://bvsms.saude.gov.br/bvs/ publicacoes/cuidado_farmaceutico_atencao_basica_saude_3.pdf. Portuguese.

38. HumanizaSUS: equipe de eeferência e apoio matricial. Brasília (Brazil): Ministério da Saúde; 2004

39. Campos GWdS, Domitti AC. Apoio matricial e equipe de referência: uma metodologia para gestão do trabalho interdisciplinar em saúde. Cad Saúde Pública. 2007;23:399-407.

40. Núcleo de apoio à saúde da familia - Volume 1: Ferramentas para a gestão e para o trabalho cotidiano. Cadernos de atenção básica, $n^{\circ} 39$. Brasília (Brazil): Ministério da Saúde; 2014.

41. Cuidados farmacêuticos melhoram resultados de tratamentos pelo país. Brasília (Brazil): Conselho Federal de Farmácia; 2017 [cited 2017 Mar 2]. Available from: www.cff.org.br/noticia.php?id=4288

42. Atenção básica. Brasília (Brazil): Ministério da Saúde; 2016 [cited 2016 Jul 2]. Available from: http://pensesus.fiocruz.br/atencao-basica

43. Nota técnica 07/2013. Estratégia e-sus atenção básica e sistema de informação em saúde da atenção básica - Sisab. Brasília (Brazil): CONASS; 2013 [cited 2016 Sep 20]. Available from: www.conass.org.br/biblioteca/wp-content/uploads/2013/01/NT-07-2013-e-SUS-e-SISAB.pdf 
44. Relação nacional de medicamentos essenciais. Brasília (Brazil): Ministério da Saúde, Secretaria de Ciência, Tecnologia e Insumos Estratégicos; 2014 [cited 2016 Aug 23]. Available from: http://bvsms.saude.gov.br/bvs/ publicacoes/relacao_nacional_medicamentos_essenciais_rename_2014.pdf

45. Série pnaum - pesquisa nacional sobre acesso, utilização e promoção do uso racional de medicamentos no Brasil [slide presentation]. Brasília (Brazil): Ministério da Saúde, Secretaria de Ciência, Tecnologia e Insumos Estratégicos; 2014 [cited 2016 Jul 1]. Available from: http:// portalarquivos.saude.gov.br/images/pdf/2014/novembro/18/PNAUMcienciasus.pdf

46. Santos V, Nitrini SMOO. Prescription and patient-care indicators in healthcare services. Rev Saúde Pública. 2004;38(6):819-34.

47. Indicadores gerais: dados gerais. Rio de Janeiro (Brazil): Agência Nacional de Saúde Suplementar; 2016 [cited 2016 Jul 18]. Available from: www.ans.gov.br/perfil-do-setor/dados-gerais

48. Avaliação de tecnologias em saúde: ferramentas para a gestão do SUS. Brasília (Brazil): Ministério da Saúde, Secretaria-Executiva, Área de Economia da Saúde e Desenvolvimento; 2009.

49. Avaliação de tecnologias em saúde: seleção de estudos apoiados pelo Decit. Brasília (Brazil): Ministério da Saúde, Secretaria de Ciência, Tecnologia e Insumos Estratégicos, Departamento de Ciência e Tecnologia; 2011.

50. Campanha: Programa Nacional de Imunizaçōes: O que é? Brasília (Brazil): Ministério da Saúde; 2016 [cited 2016 Jul 18]. Available from: http:// portalarquivos.saude.gov.br/campanhas/pni/o-que-e.html

51. Programa Nacional de Imunizaçôes - 30 anos. Brasília (Brazil): Ministério da Saúde, Secretaria de Vigilância em Saúde; 2003.

52. Domingues CMAS, Teixeira AMS. Coberturas vacinais e doenças imunopreveníveis no Brasil no período 1982-2012: avanços e desafios do Programa Nacional de Imunizações. Epidemiol Serv Saúde. 2013;22(1):9-27.
Angelita Cristine Melo, BPharm, MPharmSci, PhD, is a Professor with the Federal University São João Del-Rei and is a member of the Research Group on Epidemiology and on Public Health and the Research Group on Clinical Pharmacy, Divinópolis, Minas Gerais, Brazil

Dayani Galato, BPharm, MSc, PhD, is a Professor with the University of Brasilia and is a member of the Research Group on Access to Medicines and Responsible Use, Brasília, Brazil.

Hellen Karoline Maniero, BPharm, is Presidency Advisor of the Brazilian Federal Council of Pharmacy, and is a member of the Research Group on Access to Medicines and Responsible Use of University of Brasília, Brasília, Brazil.

Josélia Cintya Quintão Pena Frade, BPharm, MPharmCare, MHSC, is Presidency Advisor of Brazilian Federal Council of Pharmacy, Brasília, Brazil.

Tarcisio José Palhano, BPharm, is Presidency Advisor of Brazilian Federal Council of Pharmacy, Brasília, Brazil.

Wellington Barros da Silva, BPharm, MPharmSci, PhD, is a Professor at the Federal University of Sergipe, Sergipe, Brazil.

Walter da Silva Jorge João, BPharm, MFoodSciNutr, is President of the Brazilian Federal Council of Pharmacy, Brasília, Brazil.

Competing Interests: None declared.

Address correspondence to:

Walter da Silva Jorge João

Conselho Federal de Farmácia

SHIS Qi15 Lote L

Lago Sul, Brasília - DF 71635-615

Brazil

e-mail: joselia@cff.org.br 